\title{
PENELITIAN TENTANG REALITAS KEHIDUPAN SOSIAL KEAGAMAAN MASYARAKAT PETANI PANGAN DI KELURAHAN MACORAWALIE KEC. SAWITTO KABUPATEN PINRANG SULAWESI SELATAN
}

\section{SUTISN A}

\section{I}

Pelaksanaan Pembangunan Indonesia saat ini melalui beberapa tahapan, jangka pendek maupun jangka panjang kedua kategori pelaksanaan pembangunan ini tidak terlepas dari Pembangunan sektor pertanian karena sektor Pertanian memberikan andil yang besar terhadap Pembangunan selain membangun dirinya sendiri utamanya dalam peningkatan hasil melalui Intensifikasi dengan Pola Intensifikasi khusus dan Ekstensifikasi yaitu dengan jalan perluasan areal pertanian kesemua pola ini tidak lain untuk peningkatan hasil pertanian dengan menopang Pembangunan Industri,pola Intensifikasi yaitu peningkatan hasil pertanian dengan tidak memperluas areal dimana peningkatan ini memerlukan hasil industri berupa pupuk, obat pemberantasan hama dan sebagainya, sedang pola Ekstensifikasi dalam perluasan areal pertanian disamping tenaga manusia juga penggunaan mesin-mesin hasil industri.

Pembangunan ini sudah memasuki tahun pertama Pelita Lima pelaksanaan dan keberhasilan Pembangunan ini sudah menyentuh dan dirasakan oleh lapisan masyarakat khususnya masyarakat pedesaan sehingga dapat merobah pola pikir dan tingkah laku sehingga dapat merobah pola hidup masyarakat pada umum- nya. Aspek hidup masyarakat saling berpengaruh diantara aspek ekonomi berpengaruh pada aspek sosial budaya dan keagamaan demikian pula sebaliknya. Tinggi rendahnya income atau pendapatan petani pangan ini dapat mempengaruhi pola pikir dan pola pandang yang tercermin dalam pola sikap dan tingkah lakunya dan pada giliran berpengaruh pada realitas hidup masyarakat.

Sebagai tujuan penelitian ini untuk memperoleh gambaran yang jelas mengenai kondisi kehidupan sosial dan keagamaan masyarakat petani pangan di Kelurahan Macorawalie.

Kegunaan penelitian ini diharapkan berguna sebagai bahan masukan bagi penentu kebijaksanaan dalam rangka Perencanaan Pembangunan Khususnya untuk pembinaan dan pengembangan masyarakat petani pangan menuju tercapainya kesejahteraan sosial yang merata. Dan dapat pula menjadi rujukan untuk pengembangan Ilmu Pengetahuan.

Teknik pengumpulan data yang digunakan melalui observasi, wawancara, studi Dokumentasi dan telaah Pustaka; dan analisis data kualitatif akan dianalisis dengan melakukan pengkategorian penganalisaan dan interpretasi fakta, sedangkan data kuantitatif akan diolah dengan kategorisasi, distribusi frekuensi dan selanjutnya dianalisis secara Verbalisasi. 


\section{n}

Pada lokasi penelitian ini menurut catatan Sejarah selain penduduk asli yang berasal dari sebuah kampung kecil yang tertua yang terletak di bagian utara wilayah Kabupaten Pinrang yaitu Kaballangeng, selain itu tercatat pula bahwa beberapa bagian wilayah ini dihuni oleh orang-orang pendatang dari daerah sekitar terutama yang berbatasan langsung daerah Pinrang seperti daerah Enrekang dan daerah Tana Toraja. Mengenai penduduk yang berasal dari Enrekang tercatat suatu peristiwa bahwa pada Abad ke XVI, La Mappatunru anak lakilaki Bissu Tonang Arung Engrekang berangkat ke kampung Ayahnya yaitu Sawitto Timoreng Saddang, sebagai pelampiasan kegemaran melancong disamping melepas kerinduan pada sang Ayah.

Untuk menghindari kejenuhan Lamappatunru di suatu hari yang cerah bersama temannya menyeberang ke wilayah Sawitto Watang Saddang. Setelah sampai di pesisir pantai La Mappatunru lalu terpesona memandang bentangan laut seakan tak bertepi, dan hamparan tanah datar yang begitu luas yang tak pernah dijumpai sebelumnya di Enrekang. Setelah kembali di Enrekang, ia segera mengajukan usul kehadapan ibundanya agar daapt diizinkan untuk membuka tanah dan menetap di sana. Setelah direnungkan dengan matang, maka ibundanyapun pada akhirnya mengizinkan dan melepas kepergian La Mappatunru walau dengan hati yang berat. Maka berangkatlah La Mappatunru dengan rombongannya dan membawa 40 ekor kuda, beberapa ekor kerbau, serta dengan berbagai jenis bibit tanaman seperti : wijen (Bugis langnga), Keladi (Bugis Kaladi), Ubi (Bugis Lame) menuju ke tempat tujuan.
Di daerah baru tersebut, La Mappatunru dengan rombongannya membuka tanah perkebunan, dan menanam semua bibit tanaman yang dibawa dari Enrekang. Beberapa tahun kemudian, tanah perkebunan tersebut dirobah menjadi areal persawahan. Lalu sawah bekas kebun keladi dinamakan pakkaladiang, bekas kebun ubi (lame) dinamakan kampung pallamean, dan bekas kebun wijen (langnga) dinamakan kampung Langnga yang sekarang merupakan kelurahan pusat Pemerintahan Wilayah kecamatan Mattiro Sompe Kabupaten Pinrang. Sedangkan penduduk yang berasal dari Tanah Toraja mendiami daerah Pinrang bagian utara.

Kelurahan Macorawalie tempat dilakukan penelitian ini adalah sebuah kelurahan yang terletak di ujung selatan wilayah Kecamatan Sawitto atau tepatnya sebelah selatan Kecamatan Matiro Bulu, sebelah barat kelurahan Salo, sebelah utara Kelurahan Tammasarange dan sebelah timur Kelurahan Mattiro Deceng; secara keseluruhan luas wilayah Kelurahan Macorawalie lebih kurang 38,45 $\mathrm{Km} 2$ dengan rincian persawahan 1479,33 ha, perkebunan 763,07 ha, dan perumahan 144.979 ha ; sedangkan jumlah penduduk menurut lapangan pekerjaan tidak termasuk anak-anak belum usia kerja, petani pangan $62,73 \%$, pegawai negeri $22,11 \%$, ABRI $5,49 \%$, pensiunan $5,35 \%$ dan Pertukangan 4,32\%; jumlah penduduk menurut agama, Islam sebesar 98,42\%, Kristen Katolik dan Protestan sebanyak 1,46\% dan Hindu Budha adalah 0,11\%.

Dari potensi lahan dan penduduknya mayoritas petani membawa-Kabupaten Pinrang menjadi lumbung beras Sulawesi Selatan, pada Kabupaten Pinrang ini produksi padi yang dihasilkan pada Pelita IV sebanyak 1.662.747,74 ton setahun dengan tingkat 
Produktivitas 51,73 kuintal dalam satu ha, hasil sawah Kabupaten Pinrang ini dalam Pelita IV berhasil disisihkan sebanyak 239.466.613 ton setara beras untuk pengadaan pangan stock Nasional. Dengan keberhasilan ini sesuai potensi yang dimiliki utamanya keadaan alamnya yang cocok dengan pertanian tanaman pangan memberi porsi yang besar terhadap Pembangunan Sub Sektor Pertanian tanaman pangan dan menyusul sub Sektor perikanan, peternakan dan perkebunan, kesemua sub Sektor ini dicanangkan oleh Pemerintah untuk lebih dikembangkan dengan kata lain digolongkan kedalam pengwilayahan komoditas sesuai potensi alam yang dimilikinya.

\section{III}

Rumah Tangga petani di wilayah Macorawalie dalam pengolah sawahnya selain mengikuti petunjuk Pemerintah dalam hal ini penyuluh pertanian Lapangan juga masih ada dilakukan peninggalan nenek moyang mereka di antaranya waktu mau turun sawah, setelah benih akan disemaikan, setelah padi mulai berbuah, juga pada saat dimulai panen dan begitu pula setelah panen usai diadakan upacara syukuran atas keberahsilan panen yang dilaksanakannya. Usaha tani yangdilaksanakan selain anggota keluarga terlibat langsung dalam pengolahan sawah juga sudah menggunakan mekanisasi Pertanian menurut pikiran mereka dengan Mekanisasi Pertanian dapat tepat waktu turun sawah sehingga pekerjaan lain dapat terselesaikan, selain usaha taninya jalan juga usaha pertukangan guna menambah pendapatan keluarga mereka, karena jika tidak ditopang oleh pekerjaan sampingan bagaimana nasib keluarga mereka, kehidupan ekonomi rumah tangga petani termasuk kebutuhan primer dan sekunder termasuk menyekolahkan anaknya memerlukan biaya yang cukup besar, dan hasil yang berupa pendapatan petani sangat kurang karena lahan yang digarapnya adalah disewa dari pemilik. Namun waktu selesai panen sudah disisihkan sebahagian hasilnya untuk sarana pendidikan dan peribadatan serta pembangunan sarana dan prasarana sosial lain baik berupa uang tunai maupun benda.

Jika sehabis panen padi sumbangan tanpa diminta ia menyerahkan kepada pemerintah atau panitia yang sudah dibentuk, hal ini berlangsung terus menerus setiap habis panen, dengan dibangunnya sekolah di wilayah Kelurahan ini berkat bantuan swadaya masyarakat atas bimbingan Pemerintah, menurut mereka atau masyarakat petani sumbangan dengan hati ihlas tanpa diminta akan mendapat pahala yang berlipat ganda dan merupakan tabungan amal di hari kemudian, dan kalau membangun sarana dan prasarana untuk kepentingan umat manusia merupakan amal jariah dan imbalannya akan diterima kelak.

\section{IV}

Dalam pelaksanaan usaha tani mereka dari pagi hari sampai sore hari bahkan malam hari baru kembali ke rumah bersama anggota keluarga lain, dalam mengolah lahannya bila waktu subuh berangkat nanti selesai sembahyang subuh begitu pula pada waktu istirahat siang hari juga digunakan sembahyang Dhuhur dan begitu pula sore hari dan malam hari digunakan sembahyang Ashar dan Magrib; dan dalam melaksanakan puasa bulan ramadhan dilaksanakan dengan hati ihlas, dalam mengeluarkan zakat baik zakat Fitrah maupun zakat harta tidak luput olehnya, sedang pelaksanaan ibadah Haji sebagian dari mereka menunaikannya utamanya para petani pemilik.

No. 1 \& 2 Thn. I Juli / Desember 1990 
Menurut pemahaman mereka jika kita mengaku beragama khususnya agama Islam harus/ wajib dilaksanakan ajarannya dan mclaksanakan perintahNya utamanya rukun Islam dan menjauhi semua laranganNya agar hidup dan kehidupan kita tenteram dan damai yang diridhoi Tuhan Yang Maha Kuasa.

Dalam hal upacara-upacara keagamaan baik upacara hari raya Islam maupun hari Raya yang bukan Islam kesemuanya berjalan dengan baik; upacara Hari Raya Idul Fitri maupun Idhul Adha terlihat nampak kerukunan Ummat dimana hari Raya tersebut dilaksanakan pada pagi hari setelah Fajar menyingsing di ufuk timur mereka beramai-ramai dan berbondongbondong ke tempat upacara dilaksanakan dengan niat yang suci berpakaian rapi dan bersih dengan diriingi wangi-wangian ditempat tujuan.

Setelah usai sebahyang dilaksanakan dan bersalaman satu dengan lain dan memaafkan atas dosa yang diperbuatnya baik disengaja maupun tidak disengaja, menurut mereka dosa yang diperbuat dari sesama manusia harus meminta maaf langsung atau saling memaafkan agar kehidupan bathin dapat tenteram tanpa diganggu hal persangkaan buruk dalam melaksanakan usahanya. Sehubungan dengan upacara keagamaan baik seagama maupun anutan agama lain juga saling kunjung mengunjungi dan maaf memaafkan disamping ada hidangan yang disiapkan anggota keluarga, dan dalam kunjung mengunjungi berguna dan dirasakan manfaatnya dan saling tukar pandangan baik masalah keagamaan maupun usaha yang dilaksanakan dan ditekuninya baik peningkatan pengolahannya maupun pemasaran hasil. Di wilayah Kelurahan Macorawalie sudah menikmati manfaat kebedaraan Koperasi Unit Desa, Unit usaha koperasi diantaranya pemasaran hasil pertanian dari petani anggota maupun yang bukan anggota dengan pembelian standar pemerintah, karena dengan ikut berpartisipasi terhadap penggunaan sarana yang dimiliki koperasi berarti ikut aktif melaksanakan Pembangunan bangsa dan Negara yang menuju masyarakat adil dan makmur sprituil dan Materil. 


\section{DAFTAR KEPUSTAKAAN}

1). Ahmad M. Saefuddin Dr. Ir : Ekonomi 1987 dan Masyarakat dalam Perspektif Islam, Jakarta : Rajawali Pers.

2). James C. Scott: Moral Ekonomi Petani, 1981 Jakarta LP3ES.

3). Mattulada : LATOA, Suatu Lukisan 1975 Analisis Terhadap Antropologi Politik Orang Bugis Disertasi Doktor, Jakarta: Universitas Indonesia.

4). Moeljadi Banocwijoyo Prof. Dr. Ir : 1983 Pembangunan Pertanian, Nasional Surabaya.

5). Mubyarto : Pengantar Ekonomi Per1972 tanian, Jokyakarta, LP3ES.

6)............ Simposium, Sejarah 1988 Lahirnya Kabupaten Dacrah Tingkat II Pinrang.
7). Taufik Abdullah : Agama, Etos Kerja 1979 dan Perkembangan Ekonomi, Jakarta ; LP3ES.

8). Proyek Inventarisasi dan Dokumentasi 1984 Kebudayaan Daerah, Upacara Tradisional Dalam Kaitannya Dengan Peristiwa Alam dan Kepercayaan Propinsi Sulawesi, Jakarta ; Departemen Pendidikan dan Kebudayaan.

9). Proyek Inventatisasi dan Dokumentasi 1982 Kebudayaan Derah, Upacara Tradisional Daerah Sulawesi Selatan, Jakarta : Direktorat Kebudayan Departemen Pendidikan dan Kebudayaan 